\title{
SISTEM MONITORING DAN PEREKAMAN KEHADIRAN MENGAJAR DOSEN BERBASIS RFId DAN DATABASE UNTUK PENINGKATAN MUTU PENGAJARAN
}

\author{
Yul Hendra ${ }^{1,}$ Ely Nuryani ${ }^{2}$ \\ ${ }^{1}$ Program Studi Sistem Informasi \\ ${ }^{2}$ Program Studi Komputerisasi Akuntansi \\ Fakultas Ilmu Komputer Universitas Banten Jaya \\ Jl. Syeh Nawawi Albantani, Curug, Kota Serang, Banten \\ Email: yulhendra@unbaja.ac.id ${ }^{1}$, elynuryani@unbaja.ac.id ${ }^{2}$
}

\begin{abstract}
In this study there are 3 topics of discussion, namely the problem of monitoring the teaching presence of lecturers, recording data on the use of the room into a database that can be accessed by an online application in realtime. The methodology used in this study is the prototype method which has the following stages: 1. Identification of needs, 2. Building Prototype, 3. Coding, 4. Testing and Evaluation of Prototype ,. The system is created using the application of Radio Frequency Identification (RFId) technology, the PHP programming language and MySQL as the software and database. RFId technology is used as an input device when lecturers enter using the RFId Card. The RFId Card is used by lecturers for attendance that will be automatically recorded into the database along with the room, day and hour data. This system can be accessed by users through a web-based application to facilitate the Academic Section, the Financial Section and the Head of the Study Program and the leadership to monitor and track the number of lecturers' teaching attendance in class. The result is a monitoring and recording system for teaching attendance based on RFId lecturers and this database helps the Academic Section, the Finance Section and the Head of the Study Program and the leadership in monitoring and overseeing lecturer attendance
\end{abstract}

Keyword : Application, Attendance Monitoring, Lecturer, RFId

\section{PENDAHULUAN}

Kehadiran dosen dalam mengajar merupakan hal yang penting untuk diawasi dan dimonitoring karena terkait dengan mutu proses belajar mengajar. Setiap dosen yang mengajar wajib mengisi daftar hadir di fakultas masing-masing agar fakultas, program studi dan bagian penjaminan mutu dapat memantau kehadiran dosen tersebut. Namun selama ini dalam memantau kehadiran dan kedisiplinan dosen ketika memasuki ruang kelas tidak dapat terpantau dengan baik karena pada daftar hadir dosen tidak ditulis waktu tepatnya dosen tersebut 
hadir dan ada saja dosen yang mengisi daftar hadir setelah dosen tersebut selesai mengajar. Ini menjadi hambatan bagi fakultas dan program studi serta bagian penjaminan mutu untuk memantau dosen mengajar serta menentukan tingkat kedisiplinan dosen selama ini.

Mengawasi kehadiran mengajar dosen setiap hari di semua kelas yang tersedia merupakan hal yang cukup berat bagi fakultas, program studi, bagian jaminan mutu ataupun pimpinan yang lain. Banyaknya kelas yang tersedia adalah salah satu penyebab sulit dan beratnya pengawasan dan pengontrolan ini untuk dilakukan. Selama ini pengawasan yang dilakukan hanya berdasarkan absensi yang ditandatangani oleh dosen, seandainya dosen melakukan kecurangan dan mahasiswa tidak ada yang melaporkan maka tidak akan terdeteksi ketidak hadiran dosen tersebut. Sesuai dengan Peraturan Menteri Pendidikan dan Kebudayaan Nomor 49 Tahun 2014 Tentang Standar Nasional Pendidikan Tinggi Pasal 10 tentang standar proses pembelajaran, maka penelitian ini menjadi sangat penting dilakukan untuk mendukung penerapan dari Peraturan Menteri tersebut.

Untuk melakukan fungsi pengawasan ini maka diperlukan alat dan sistem yang mampu bekerja secara otomatis mencatat dan merekam data kehadiran mengajar dosen secara realtime, aman dan cepat. RFId atau Radio Frequency Identification adalah teknologi yang menggunakan gelombang radio untuk mengidentifikasi manusia atau objek secara otomatis. Metode yang paling sering digunakan adalah untuk menyimpan serial number yang menunjukkan identitas seseorang atau benda, pada sebuah microchip yang disertakan pada antena (chip dan antena adalah RFId transponder atau sebuah tag RFId). RFId ini disimpan di pintu ruangan kelas berfungsi untuk membuka dan mengunci pintu sekaligus merekam data dosen yang memasuki ruangan kelas tersebut.

Data dosen dimasukan kedalam RFId Card yang sekaligus bisa digunakan sebagai kartu identitas dosen. Ketika dosen hendak masuk ke ruang kelas untuk memulai proses belajar dan mengajar, maka dosen yang bersangkutan cukup menempelkan atau mendekatkan RFId Card tersebut kepada RFid Reader yang sudah terpasang di pintu masuk kelas, maka secara otomatis RFId Reader akan melakukan otentifikasi terhadap data yang ada di RFId Card, jika data valid maka pintu ruangan kelas akan terbuka dan data dosen, data ruangan, data hari dan jam 
akan tersimpan ke database. Dengan Bahasa sederhana bisa kita jelaskan bahwa kita akan bisa mengetahui semua track dan record penggunaan ruangan kelas, hari dan jam berapa kita akan mengetahui siapa dosen yang masuk keruangan dan bisa memantau kehadiran dosen di ruangan kelas dan semua data ini akan tersimpan kedalam database. Untuk pengimplementasikan hasil penelitian ini dilakukan di Universitas Banten Jaya.

\section{METODOLOGI PENELITIAN}

Dalam penelitian ini digunakan metodologi Prototype, tahapan dalam metode ini adalah sebagai berikut:

1) Identifikasi Kebutuhan

Untuk melakukan identifikasi kebutuhan serta menganalisa permasalahan maka disajikan menggunakan diagram tulang ikan sebagai berikut:

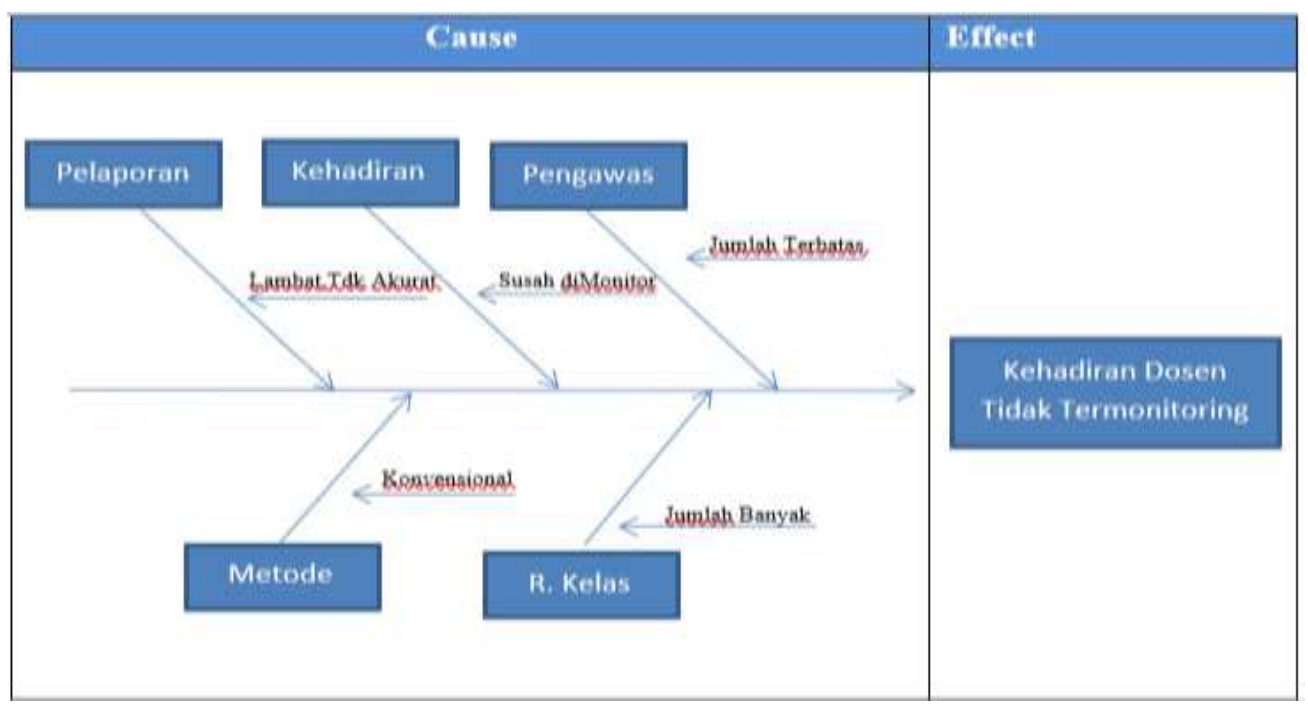

Gambar 1. Diagram Tulang Ikan Identifikasi Kebutuhan

2) Membangun Prototype

Membuat pemodelan perancangan sistem menggunakan menggunakan Unified Modeling Language (UML). Baik perancangan perangkat keras ataupun perancangan interface perangkat lunaknya 


\section{3) Coding}

Melakukan Coding atau pembuatan scripts perangkat keras menggunakan Arduino dan membuat script untuk aplikasi menggunakan Bahasa pemrograman PHP dan Database Mysql.

4) Pengujian dan Evaluasi Prototype

Melakukan pengujian terhadap sistem yang sudah dibangun guna menemukan kesalahan-kelasahan yang mungkin terjadi, dan seterusnya untuk dilakukan perbaikan atas kesalahan atau error tersebut.

Tabel 1. Daftar Kebutuhan Alat (Tools Requirement)

\begin{tabular}{|c|c|c|c|}
\hline No & Nama Alat & Bentuk Alat & Fungsi \\
\hline 1 & $\begin{array}{l}\text { Arduino } \\
\text { Uno R3 }\end{array}$ & Gambar 2. Arduino Uno R3 & $\begin{array}{l}\text { Spesifikasi : } \\
\text { - Mikrokontroler } \\
\text { ATmega328, Daya 5V } \\
\text { - Teganan Input } \\
\text { (rekomendasi) 7-12V } \\
\text { - Teganan Input (batasan) } \\
\text { 6-20V } \\
\text { - Pin I/O Digital } 14 \text { (of } \\
\text { which } 6 \text { provide PWM } \\
\text { output) } \\
\text { - Pin Input Analog 6 } \\
\text { - Arus DC per Pin I/O } 40 \\
\text { mA } \\
\text { - Arus DC per Pin I/O } \\
\text { untuk PIN 3.3V 50 mA } \\
\text { - Flash Memory 32 KB } \\
\text { (ATmega328) dimana 0.5 } \\
\text { KB digunakan oleh } \\
\text { bootloader } \\
\text { - SRAM 2 KB } \\
\text { (ATmega328) } \\
\text { - EEPROM 1 KB } \\
\text { (ATmega328) } \\
\text { - Clock Speed 16 MHz } \\
\text { Fungsi : M Microkontroller } \\
\text { Sebagai mempram dan } \\
\text { untuk memprogram } \\
\text { mengontrol komponen- } \\
\text { komponen yang terhubung } \\
\text { terhadapnya }\end{array}$ \\
\hline
\end{tabular}




\begin{tabular}{|c|c|c|c|}
\hline 2 & $\begin{array}{l}\text { RFId } \\
\text { Reader - } \\
\text { RC522 }\end{array}$ & 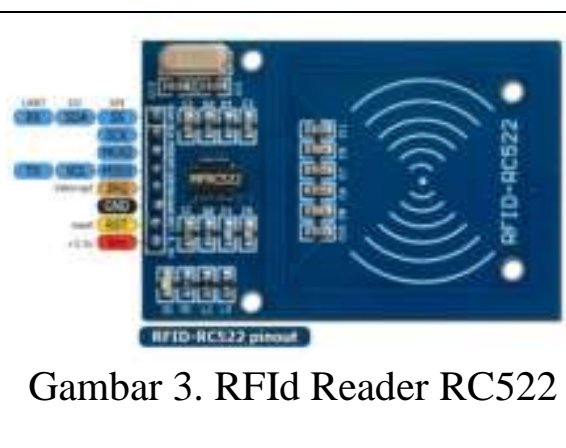 & $\begin{array}{l}\text { Spesifikasi : } \\
\text { Radio Frequency } \\
\text { Identification (RFId) Type } \\
\text { RC522 } \\
\text { Fungsi : } \\
\text { Untuk membaca RFid Card } \\
\text { dan sebagai alat yang jadi } \\
\text { masukan untuk data } \\
\text { kehadiran dan penggunaan } \\
\text { ruangan ke dalam Database }\end{array}$ \\
\hline 3 & $\begin{array}{l}\text { RFId } \\
\text { Card }\end{array}$ & Gambar 4. RFId Card & 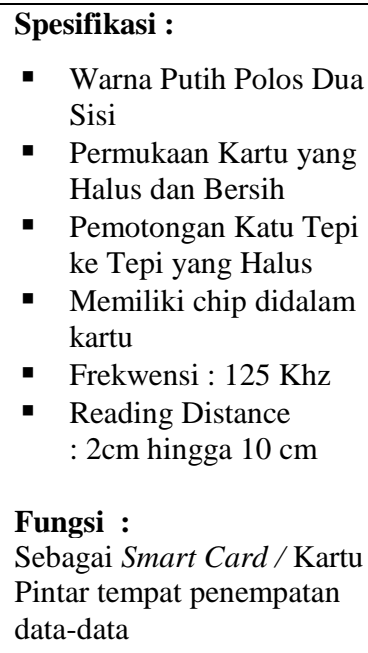 \\
\hline 4 & $\begin{array}{l}\text { Solenoid } \\
\text { Door } \\
\text { Lock }\end{array}$ & Gambar 5. Selenoid Door Lock & $\begin{array}{l}\text { Spesifikasi : } \\
\text { - } 125 \mathrm{KHz} \\
\text { - } 1 \mathrm{Kbyte} \text { EEPROM (768 } \\
\text { free bytes availability) } \\
\text { - } 2.5 \sim 10 \mathrm{~cm}(1-4 \mathrm{in} .) \\
\text { - } 85.6 \times 54 \times 0.8 \mathrm{~mm} \\
\text { - } \quad \text { PVC } \\
\text { - } \quad \text { White } \\
\text { - } 5 \mathrm{~g} \pm 0.5 \mathrm{~g} \\
\text { Fungsi : } \\
\text { Untuk mengunci dan } \\
\text { membuka pintu secara } \\
\text { eletronik }\end{array}$ \\
\hline 5 & $\begin{array}{l}\text { Display } \\
\text { LCD }\end{array}$ & $\begin{array}{l}\text { This is a } 2 \times 16 \\
\text { line LCD [isfisy } \\
\text { Gambar 6. Display }\end{array}$ & $\begin{array}{l}\text { Spesifikasi : } \\
\quad \text { LCD } 16 \text { x } 2 \\
\text { - } 16 \text { PIN } \\
\text { Fungsi : } \\
\text { Untuk menampilkan } \\
\text { data/informasi supaya bisa } \\
\text { dilihat oleh pengguna }\end{array}$ \\
\hline
\end{tabular}




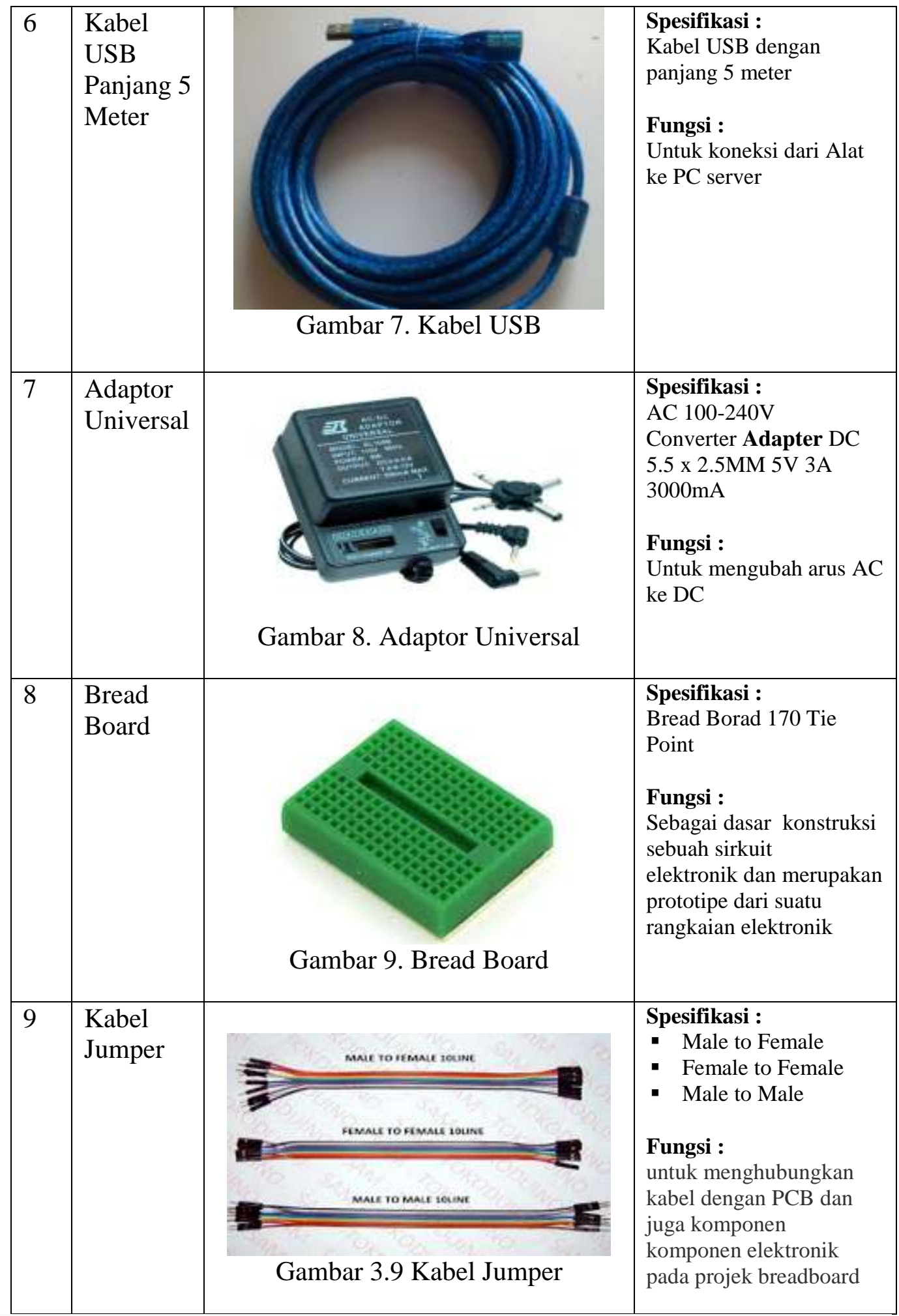




\section{HASIL DAN PEMBAHASAN}

\section{Unified Modeling Language (UML)}

Dalam menggambarkan sistem yang dirancang, digunakan pemodelan unified modeling language (UML) yang terdiri atas use case diagram, activity diagram, sequence diagram dan class diagram.

1) Use Case Diagram

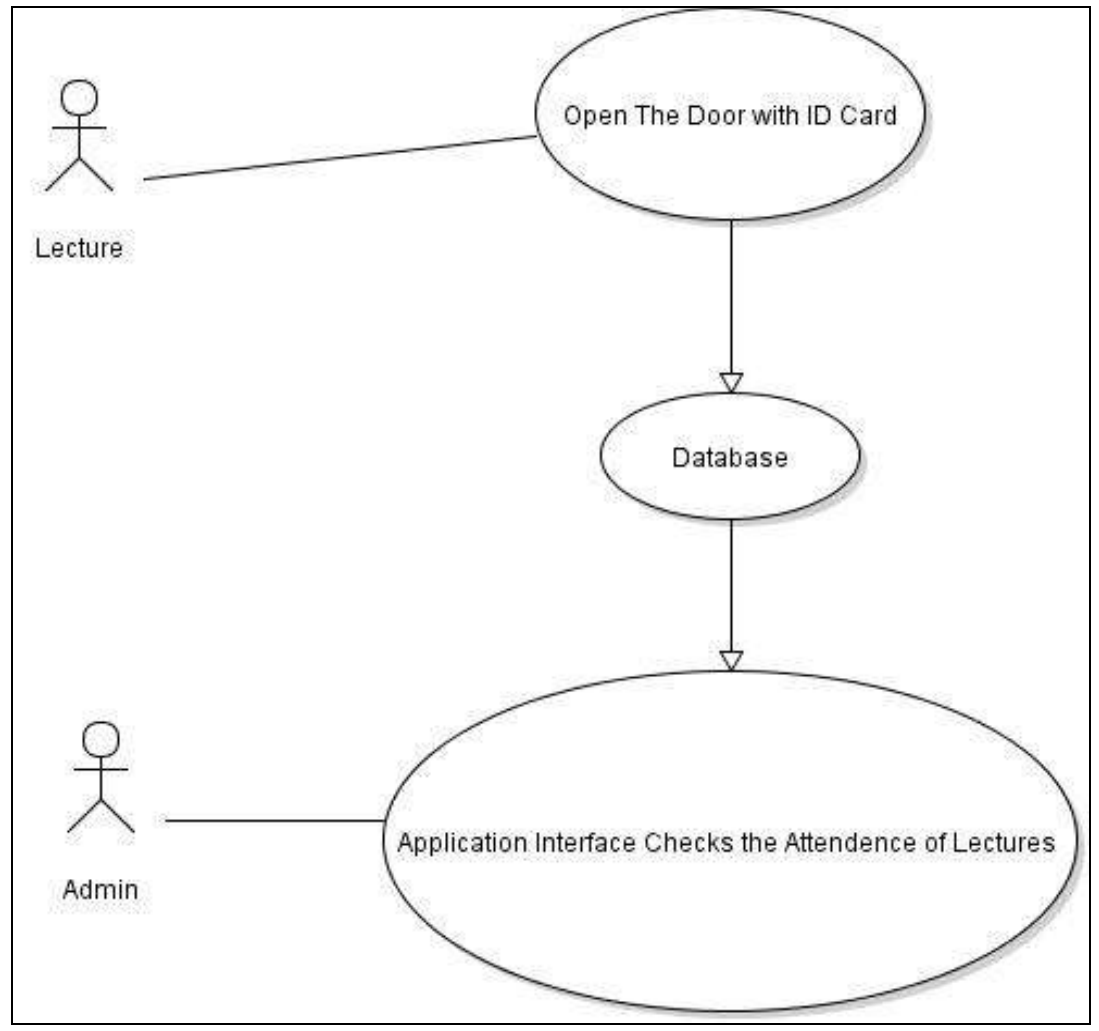

Gambar 10. Use Case Diagram Sistem 
2) Actvity Diagram

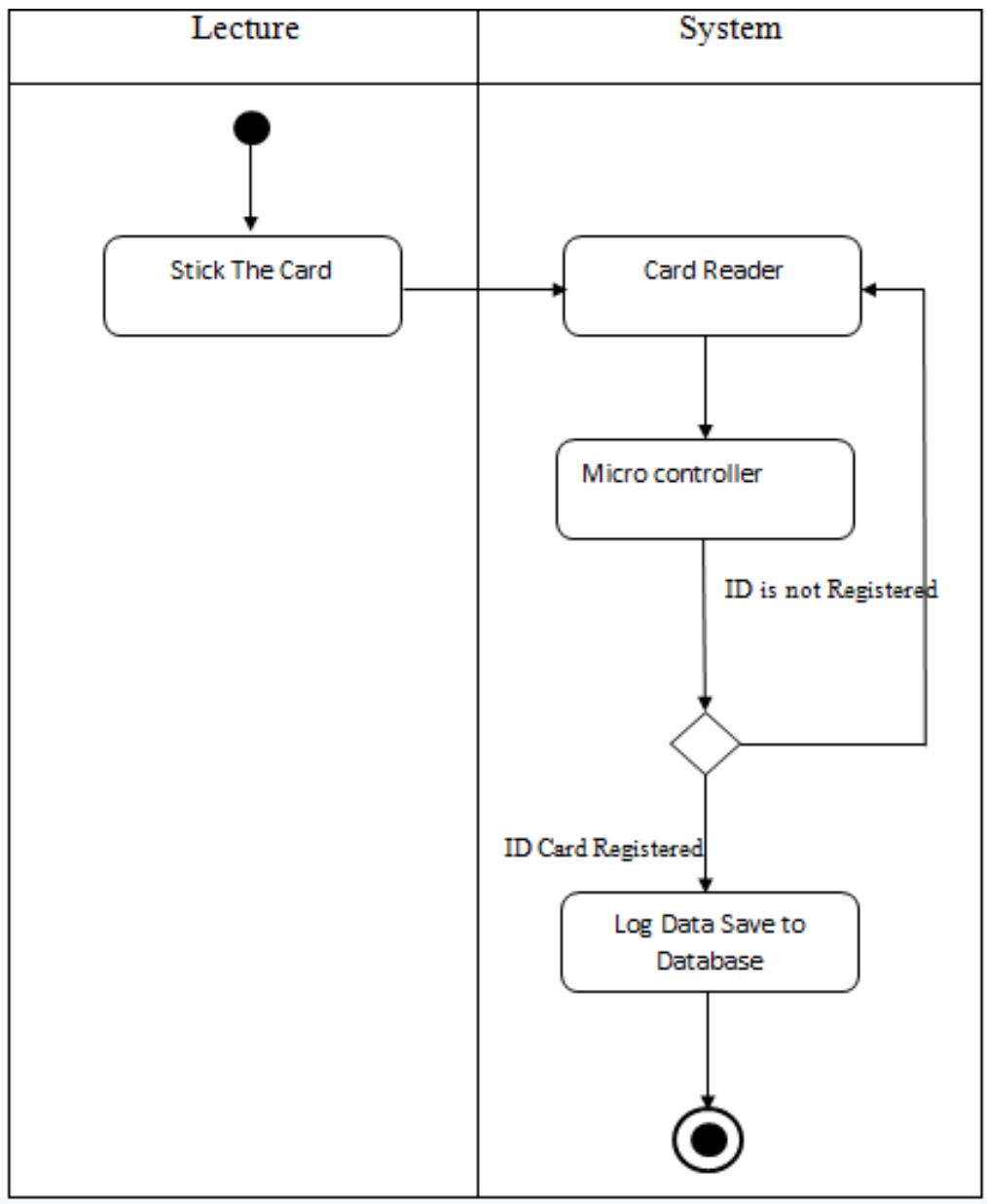

Gambar 11. Activity Diagram Dosen Masuk Ruang Kelas

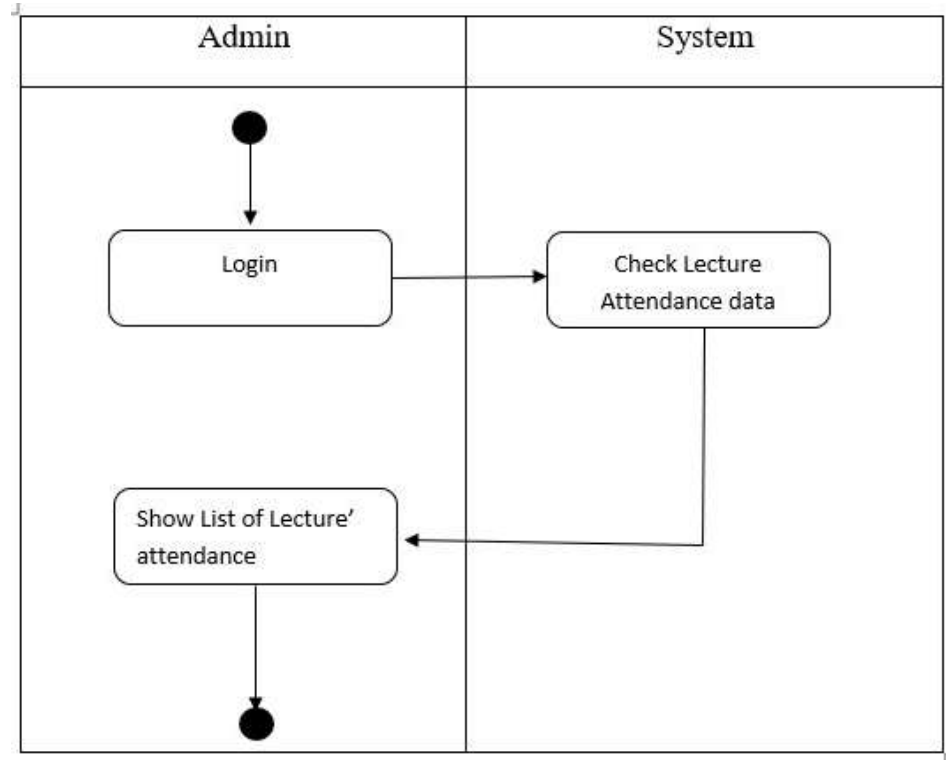

Gambar 12. Activity Diagram Memantau Kehadiran Dosen 


\section{3) Sequence Diagram}

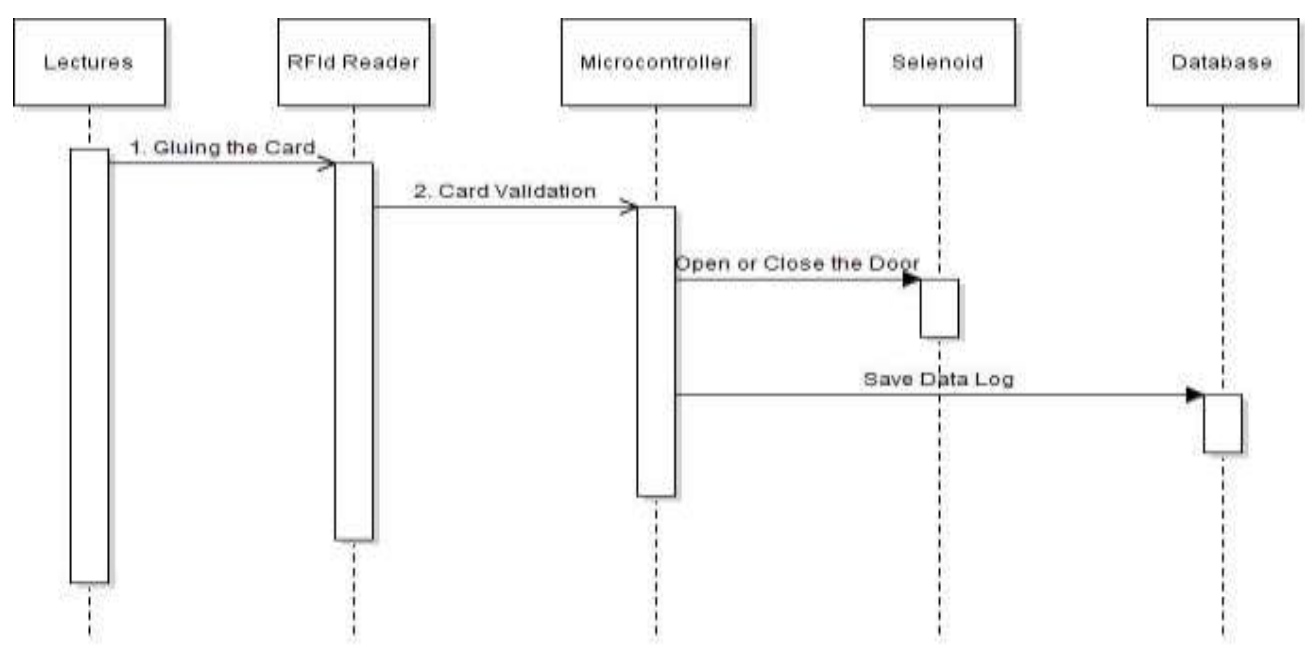

Gambar 13. Sequence Diagram Dosen Masuk Ruang Kelas

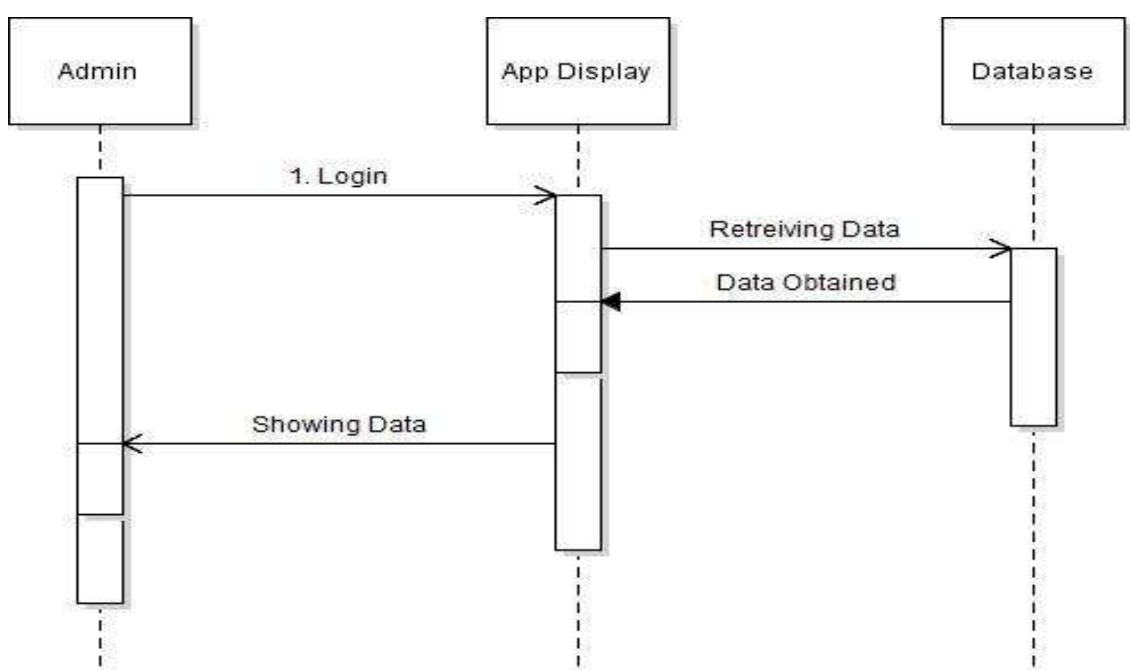

Gambar 14. Sequence Diagram Memantau Kehadiran Dosen 
4) Class Diagram

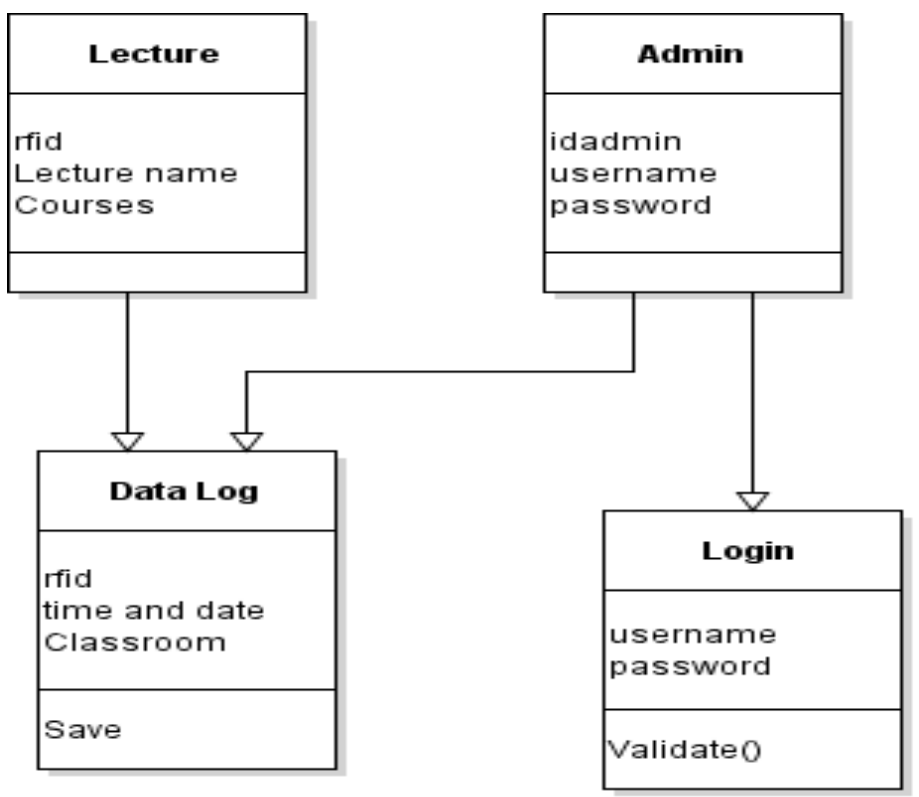

Gambar 15. Class Diagram Sistem Monitoring Kehadiran Dosen

\section{Wiring Diagram}

Wiring Diagram menggambarkan struktur atau rangkaian komponen yang dihubungkan dengan pin pada mikrokontroler, antara lain RFID Reader, Relay Module, Photoresistor Module, Reedswitch dan LCD.

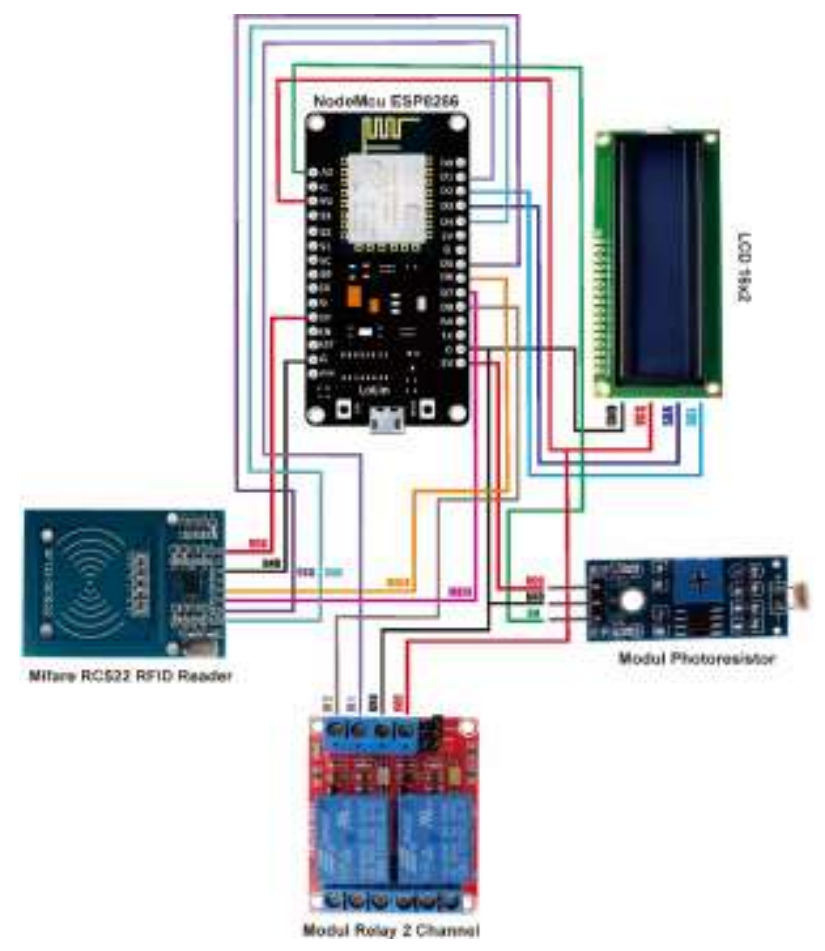

Gambar 16. Wiring Diagram Alat Sistem Monitoring Kehadiran Dosen 


\section{Prototype Program}

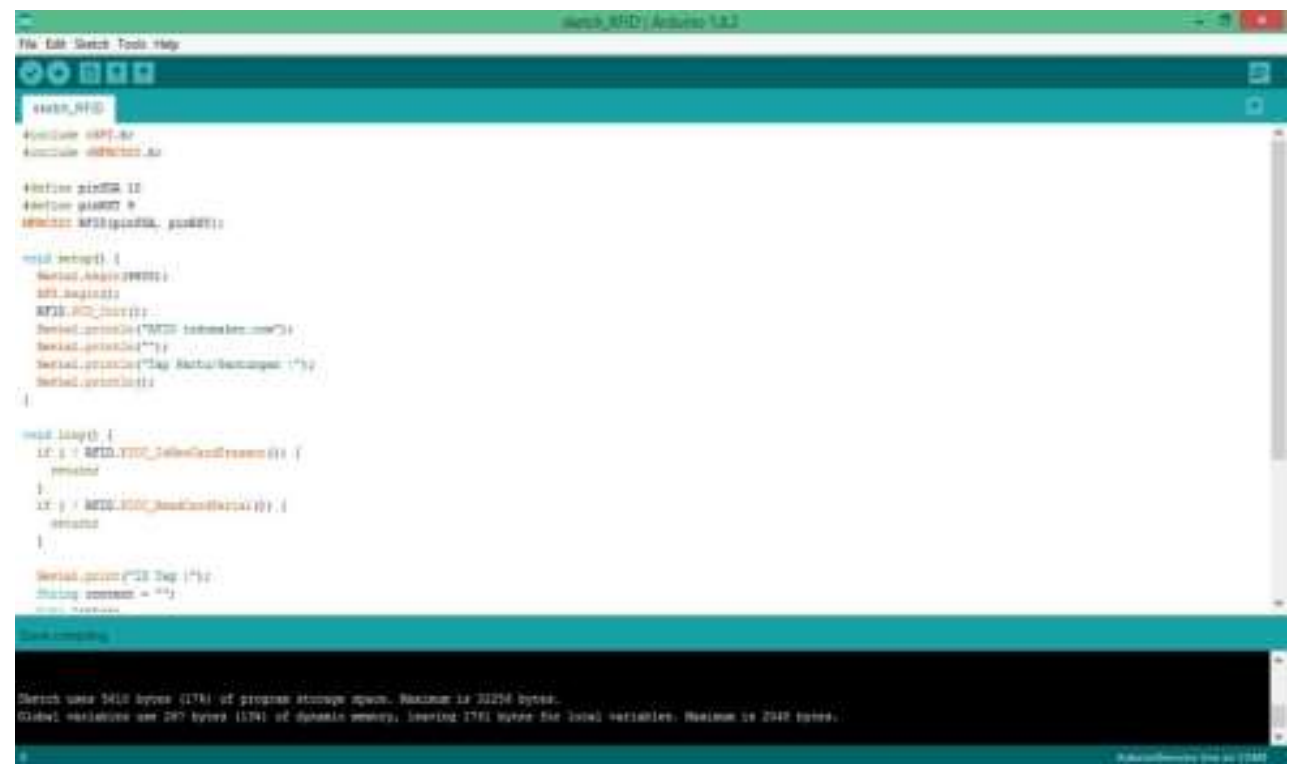

Gambar 17. Tampilan Coding IDE Arduino

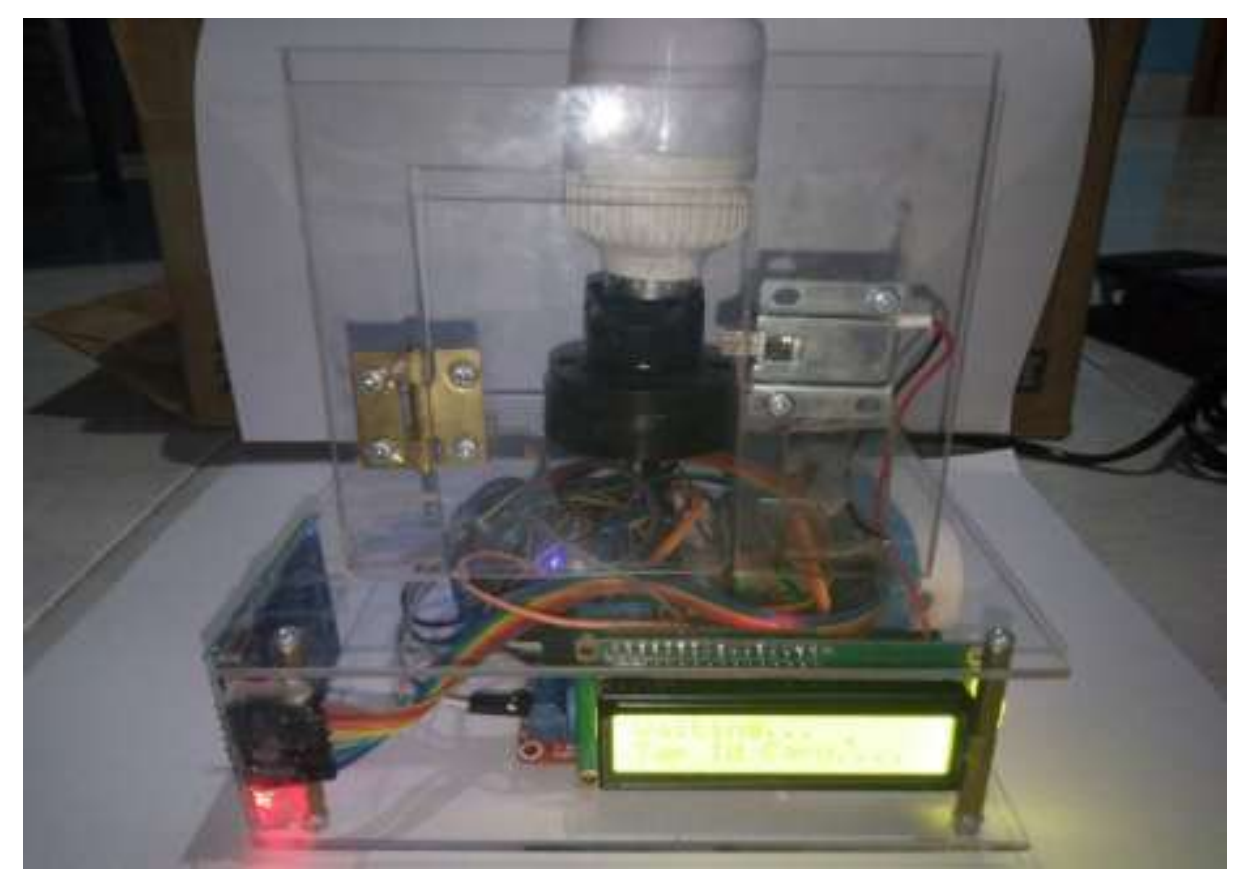

Gambar 18. Prototype Alat 


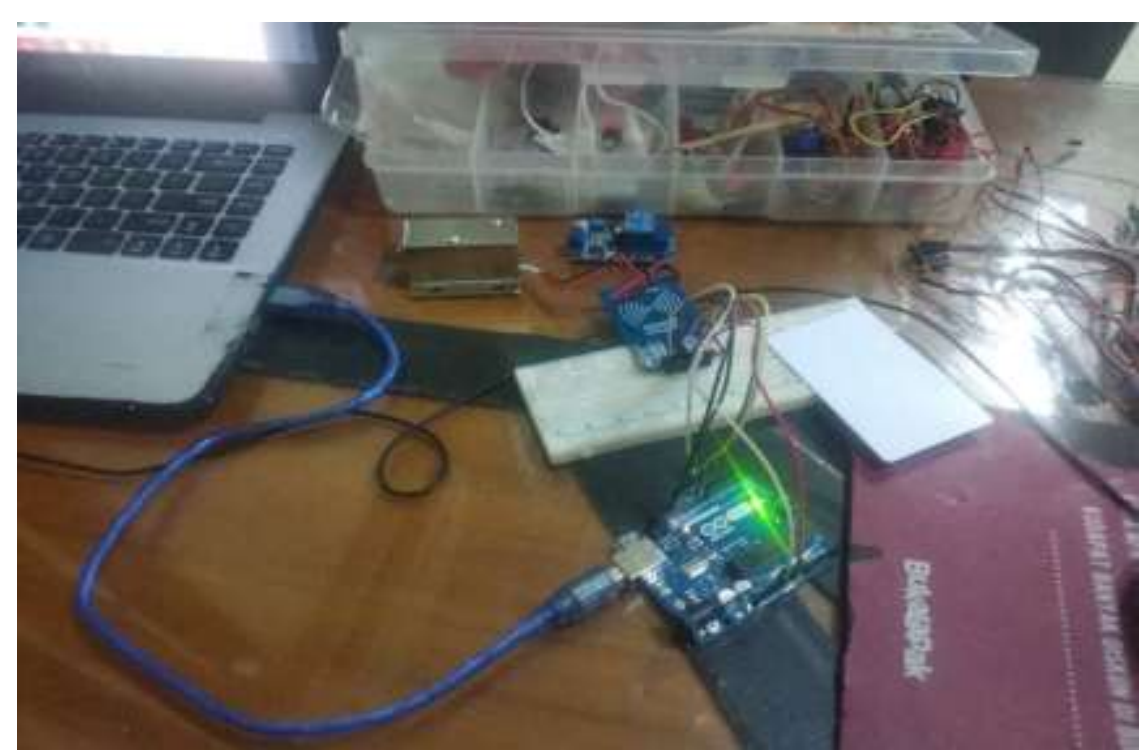

Gambar 19. Proses Perakitan Alat

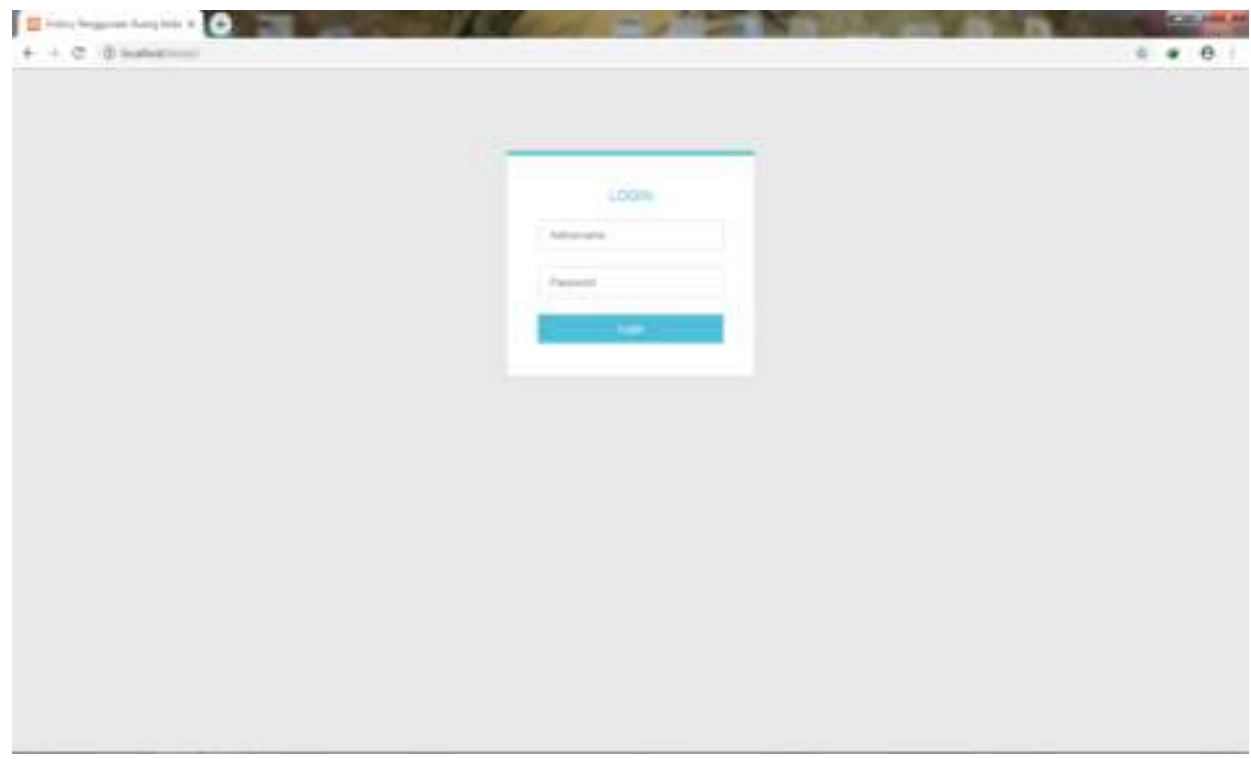

Gambar 20. Tampilan Login Aplikasi 


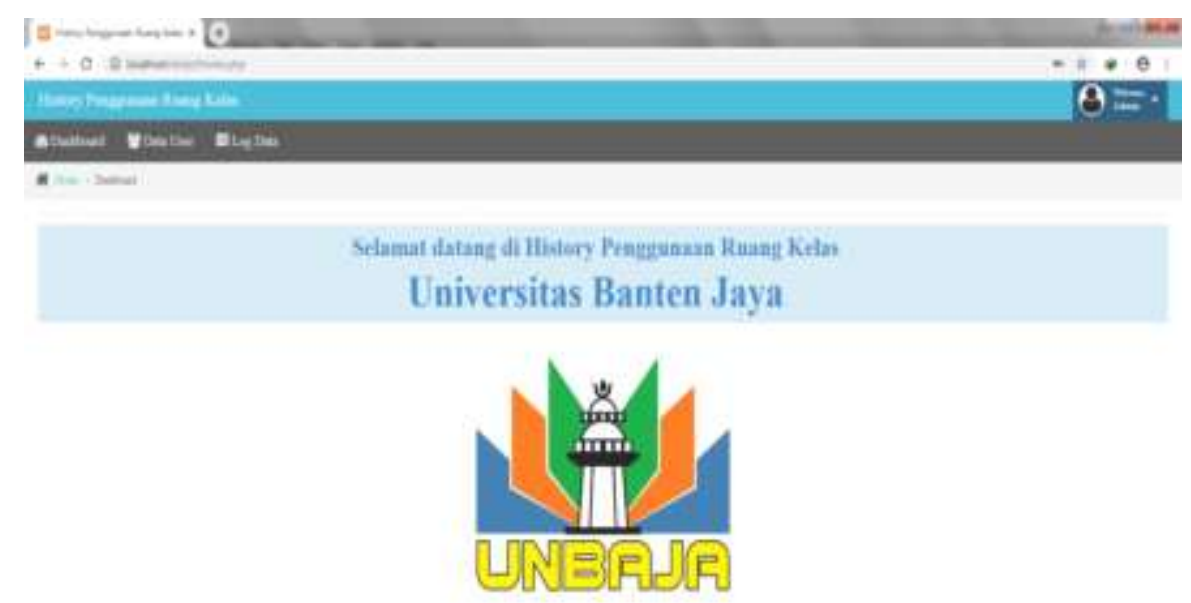

Gambar 21. Tampilan Menu Aplikasi

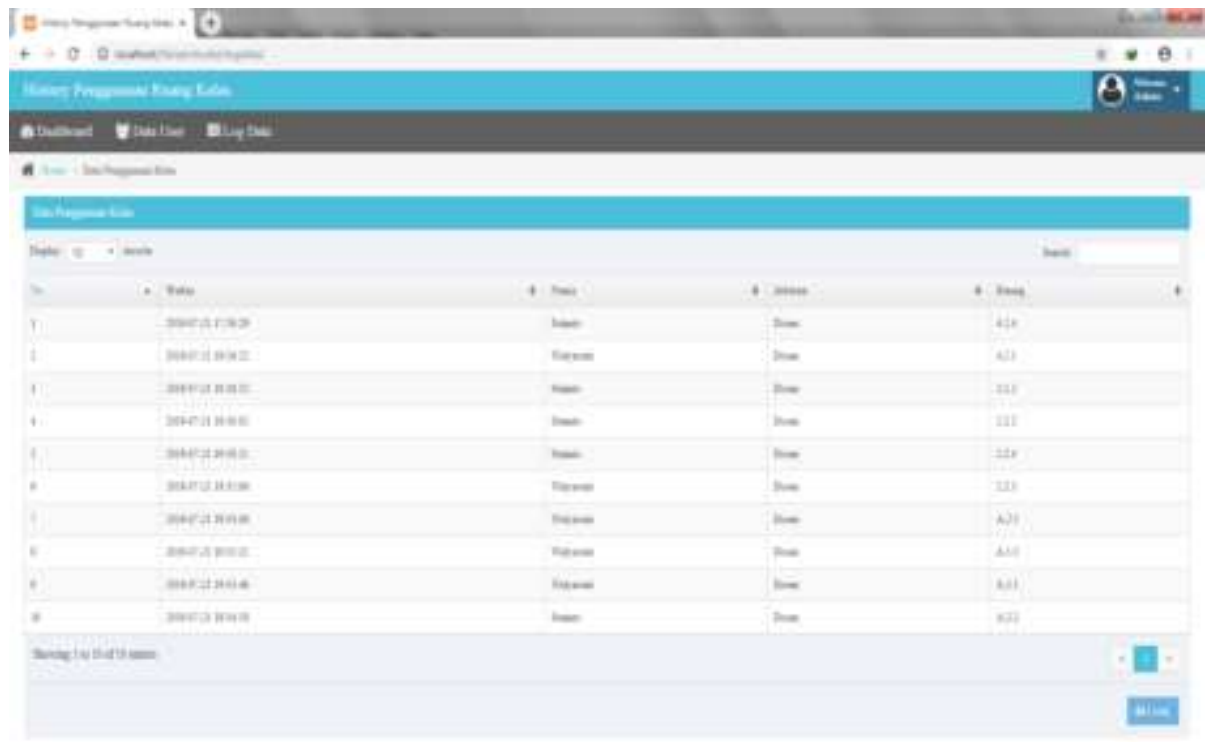

Gambar 22. Pemantauan Penggunaan Ruang Melalui Aplikasi

\section{KESIMPULAN}

Berdasarkan penelitian yang dilakukan oleh penulis memperoleh kesimpulan sebagai berikut :

1. Dengan Alat ini penggunaan ruangan dapat terekam secara otomatis dan bisa ditelusuri trackrecord-nya 
2. Sistem ini dapat memberikan kemudahan bagi ketua program studi untuk merakam kehadiran Dosen.

3. Dengan Sistem ini yang terdiri dari Perangkat keras dan perangkat lunak dapat menyajikan informasi penggunaan ruangan dan kehadiran Dosen secara cepat melalui aplikasi berbasis web.

\section{REFERENSI}

Awang Hendrianto, Dessyanto Boedi Prasetyo, 2015, PRESENSI PERKULIAHAN PRODI TEKNIK INFORMATIKA UPN "VETERAN" YOGYAKARTA BERBASIS KARTU PINTAR RFID dari http://jurnal.upnyk.ac.id/index.php/semnasif/article/view/1366/1241 diakses tanggal 16 April 2019

George Pri Hartawan, Indra Griha Tofik Isa, APLIKASI ABSENSI PERKULIAHAN DENGAN MENGGUNAKAN MIKROKONTROLER ARDUINO BERBASIS RFId dari http://eprints.ummi.ac.id/197 diakses tanggal 16 April 2019

Paulus et all, 2013, SISTEM ABSENSI BERBASIS RADIO FREQUENCY IDENTIFICATION (RFID) PADA MIKROSKIL dari https://mikroskil.ac.id/ejurnal/index.php/jsm/article/view/115/83 diakses tanggal 16 April 2019

Santoso, Wan Yuliyanti, 2016, Perencanaan dan Pembuatan Aplikasi Absensi Dosen Menggunakan Radio Frequency Identification (RFID) (Studi Kasus $\begin{array}{llll}\text { Politeknik Negeri } & \text { Tanah }\end{array}$ http://ejournal.itn.ac.id/index.php/seniati/article/view/204/197 diakses tanggal 16 April 2019

Tora Fahrudin, 2011, Pencatatan dan Pemantauan Kehadiran Perkuliahan di Lingkungan Politeknik Telkom Berbasis RFID dan Aplikasi Web dari http://journals.telkomuniversity.ac.id/knip/article/download/532/392 diakses tanggal 16 April 2019 